\title{
Effect of Harvest Season on the Fuel Properties of Sida hermaphrodita (L.) Rusby Biomass as Solid Biofuel
}

\author{
Nikola Bilandžija ${ }^{1}$, Tajana Krička ${ }^{2, *}$, Ana Matin ${ }^{2}$ (D) Josip Leto $^{3}$ and Mateja Grubor ${ }^{2}$ (i) \\ 1 Department of Agricultural Engineering, University of Zagreb Faculty of Agriculture, \\ Svetošimunska cesta 25, 10000 Zagreb, Croatia; nbilandzija@agr.hr \\ 2 Department of Agricultural Technology, Storage and Transport, University of Zagreb Faculty of Agriculture, \\ Svetošimunska cesta 25, 10000 Zagreb, Croatia; amatin@agr.hr (A.M.); mgrubor@agr.hr (M.G.) \\ 3 Department of Field Crops, Forage and Grassland, University of Zagreb Faculty of Agriculture, \\ Svetošimunska cesta 25, 10000 Zagreb, Croatia; jleto@agr.hr \\ * Correspondence: tkricka@agr.hr; Tel.: +385-1-239-3818
}

Received: 2 November 2018; Accepted: 1 December 2018; Published: 4 December 2018

check for updates

\begin{abstract}
Biomass obtained from cultivated energy crops is one of the raw materials with the highest potential in renewable energy production. Although such biomass can be used in production of lignocellulose bioethanol, it is currently mostly used as solid fuel for generating heat and/or electric energy via combustion processes. Calorific values, proximate and ultimate analysis, cell structure and micro- and macro-elements data are considered as basic parameters in the valorization of fuel properties during biomass combustion processes. Energy crops are cultivated with the aim to produce the largest possible quantity of biomass with minimal agro-technical inputs. One of these crops is Sida hermaphrodita (L.) Rusby. Given the fact that the chemical composition of biomass is influenced by a number of agro-ecological and agro-technical factors, the aim of this work was to determine the fuel properties of Sida hermaphrodita biomass obtained from three different harvest seasons (autumn, winter and spring) and cultivated in the area of the Republic of Croatia. On the basis of these investigations it was possible to conclude that harvest delaying towards spring season had a positive impact on suitability of using biomass of Sida hermaphrodita in the combustion process, which primarily means significant lowering the contents of moisture $(18.64 \%)$, ash $(1.94 \%)$, and nitrogen $(0.65 \%)$, but also means increasing the contents of fixed carbon (6.21\%) and lignin $(25.45 \%)$.
\end{abstract}

Keywords: perennial energy crop; delayed harvest; combustion properties; cell wall composition

\section{Introduction}

According to the objectives of the Framework for Climate and Energy Policies until 2030, 21st UN Conference on Climate Changes (Paris Climate Agreement—cop 21), Biofuels and Indirect Land Use Change (ILUC) and Renewable Energy Directive (RED II) [1-4], biomass and biofuels are important segments in the Europe's aim to become a self-sustainable low-carbon society. A promising and multifunctional way to protect national energy security can be a substitution of fossil energy by bioenergy, which can slow down climate change and improve rural economy [5]. Thermochemical conversion of biomass is the most commonly used way for using bioenergy crops and agricultural residues to fulfil energy needs [6]. Generally, biomass conversion technologies are considered as an environmentally friendly process [7].

Sustainable development of biomass resources for energy purposes requires knowledge of the biomass supply capacity as well as biomass quality $[8,9]$. Fuel properties data are very important for valorization of biomass in the combustion process. Such information is usually obtained by means of ultimate analysis, proximate analysis, calorimetry (for higher heating value) [10], determination of 
lignocellulosic composition and contents of micro- and macro-elements. Fuel properties of biomass vary significantly and the chemical composition and physical characteristics are greatly affected by the stage of vegetation [11]. The elemental content is commonly influenced by genetically determined properties, environmental conditions, such as soil traits (fertility, $\mathrm{pH}$ ), weather features (precipitations) and plant agro-technical measures [12]. Biomass carries a potential to supply a competitive and sustainable source of energy in the future. It can be converted into a variety of energy products such as electricity, process heat, and engine fuel [13].

One of the most promising sources of raw materials for energy production are perennial energy crops. There are a number of characteristics that make energy crops a good source of biomass. These characteristics are: high yield, cold tolerance, $\mathrm{C} 4$ photosynthesis, perenniality and a low requirement for inputs [14]. Also, it is important to emphasize the potential to cultivate energy crops on poor quality soil (marginal soils), which has a directly impact on the food/feed vs. fuel production conflict.

Sida hermaphrodita (L.) Rusby (Virginia mallow) is classified as perennial energy crop. Sida hermaphrodita, belongs to the mallow family (Malvaceae), and is native to North America. It is not a short rotation woody crop (SRWC) or a perennial grass (e.g., miscanthus) but rather, by its chemical content and stem structure, it is a soft woody herbaceous energy crop [15].

Mehmood et al., [16] showed maximum yields of energy crops on marginal soils, ranging from 9-20 tha $\mathrm{t}^{-1}$ (Sida hermaphrodite), 15-19 $\mathrm{tha}^{-1}$ (Miscanthus spp.), 1-22 $\mathrm{t} \mathrm{ha}^{-1}$ (Panicum virgatum L.) and $36 \mathrm{t} \mathrm{ha}^{-1}$ (Arundo donax). If cultivation is carried out under more favorable agro-ecological conditions it is possible to achieve more yields, Mantineo et al. [17] reported a Miscanthus yield of $26.9 \mathrm{tha}^{-1}$ and Arundo donax $38.8 \mathrm{t} \mathrm{ha}^{-1}$. Borkowska and Molas [15] reported that the biomass yield of Sida hermaphrodita was significantly affected by environmental factors, especially weather conditions and farm management. The yields of the investigated culture range from 15 to $20 \mathrm{tha}^{-1}$ [18]. In demanding agroecological cultivation conditions with the addition of sewage sludge, yields were in the range of 9 to $11 \mathrm{tha}^{-1}$ [19], while average yield of dry matter of over $11 \mathrm{tha}^{-1}$ was observed during cultivation on Light Soil. Tworkowski et al. [20] found dry matter yields of Sida hermaphrodita of 11.2 to $12.7 \mathrm{t} \mathrm{ha}^{-1}$ in February, depending on the variety of planting material and fertilizer treatments. As with other perennial crops used for energy production, in the first year of growing there are no economically significant biomass yields [21] as they are expected to occur in the third or fourth year of the crop's age.

However, the great challenge in cultivating and using of biomass energy crops is to select the appropriate harvest seasons. Dry matter yield as well as biomass quality in the greatest extent depend on harvest time, and thus the direction of biomass used to produce different biofuels.

Kiesel et al. [22] reported that the optimal harvest season for combustion depends on the yield losses, quality of harvested biomass and nutrient offtake (long-term environmental performance). Delayed harvesting affects biomass losses due to leaf fall, stem breakage, harvesting and collection efficiency [23]. By investigating the yield losses due to delayed harvest, Zub et al. [24], Larsen et al. [25] determined the losses of Miscanthus to range from 34 to $42 \%$, while Adler et al. [26] cited biomass losses of $40 \%$ for Panicum virgatum $\mathrm{L}$.

Exploring four different energy cultures, Nazlia et al. [27] have found that delayed harvesting of miscanthus, switchgrass, and giant reed also affect biomass changes. Namely, winter harvest leads to significantly lower moisture and ash contents, thus improving the quality of biomass for the combustion process. The expected lower moisture is due to natural drying in the field [28], while ash reduction may relate to the loss of leaf mass as the leaves have high mineral and ash contents [29].

Moisture content in Sida hermaphrodita biomass decreases from about $40 \%$ in November to about $20 \%$ in January [21]. However, delayed harvest may also have undesirable consequences on the quality of biomass. Exploring the potential of Miscanthus in biogas production Kiesal and Lewanowski [30] determined the reduced production of methane in relation to three different harvest times (July/August/October). The type of storage influences the characteristics of biomass such as its moisture content [31]. Depending on the biomass type and the climatic conditions, two basic types of biomass storages can be used: covered for dried biomass and open-air storages for biomass with 
higher moisture content [32]. The aim of this paper is to determine fuel properties (calorific value, proximate and ultimate analysis, cell structure and some micro/macro-elements) of Sida hermaphrodita biomass from three harvest seasons (autumn, spring and winter). In order to determine the quality of the investigated biomass as a solid biofuel, the obtained results will be compared with typical values stated in the technical specification CEN/TS 14961:2005 [33]. Given the fact that this specification does not contain values for Sida hermaphrodita biomass, the comparison will be based on the values defined for Miscanthus.

\section{Materials and Methods}

\subsection{Materials}

Experimental fields of Sida hermaphrodita were established at Ivanić Grad, Lepšić $\left(48^{\circ} 84^{\prime}\right.$ E; $50^{\circ} 65^{\prime} \mathrm{N}$ ), in Zagreb County (western part of Croatia) during the spring of 2014, and the investigations started in the autumn of 2016. Soil cultivation was carried out with classical agro-techniques, without fertilization, pesticide application and irrigation during the vegetation period.

The content of nutrients in the soil and soil reaction (soil $\mathrm{pH}$ ) of the experimental site were analyzed in the laboratory of the Department of Plant Nutrition (University of Zagreb, Faculty of Agriculture). Table 1 presents the soil nutrient content and soil characteristics of the experimental site.

Table 1. Soil nutrient content and soil reaction of the experimental site.

\begin{tabular}{cccccccc}
\hline \multirow{2}{*}{ Location/Investigated Parameters } & \multicolumn{2}{c}{$\mathbf{p H}$} & \multicolumn{2}{c}{$\%$} & \multicolumn{2}{c}{$\mathbf{m g} / \mathbf{1 0 0} \mathbf{g}$ Soil } \\
\cline { 2 - 8 } & $\mathbf{H}_{\mathbf{2}} \mathbf{O}$ & $\mathbf{1} \mathbf{M ~ K C l}$ & $\mathbf{O} . \mathbf{M}$ & $\mathbf{N}$ & $\mathbf{P}_{\mathbf{2}} \mathbf{O}_{\mathbf{5}}$ & $\mathbf{K}_{\mathbf{2}} \mathbf{O}$ \\
\hline Ivanić Grad & 5.39 & 4.73 & 1.79 & 0.09 & 8.98 & 22.0 \\
\hline
\end{tabular}

\section{Climatic Conditions}

The Ivanić Grad area has a moderate continental climate [34]. Throughout the year it is in a circulation belt of moderate width where the state of the atmosphere is very variable. According to Köppen's Climate Classification, this area has a "Cfwbx" climate, which is a moderately warm rainy climate. According to the closest climatological station data (1981-2010), the warmest month is usually July (with average temperature of $21.4^{\circ} \mathrm{C}$ ), or, less frequently, August or June. The coldest month on average is January $\left(0.5^{\circ} \mathrm{C}\right)$, or February or December, which occurs more rarely. The temperature conditions of spring and autumn are almost the same. As for annual rainfall, there are two roughly equal maximum rainfall levels in June and September $(93.0 \mathrm{~mm}$ or $97.3 \mathrm{~mm}$ ) and the secondary maximum in November $(82.3 \mathrm{~mm})$, while the minimum rainfall is observed in the winter months of January and February ( 48.3 and $44.5 \mathrm{~mm}$, respectively). According to the variation values coefficient, the prevailing rainfall rates are observed in January and August ( $\mathrm{cv}=65 \%$ and $64 \%$ respectively), and the most stable in June ( $\mathrm{cv}=44 \%)$. Annual rainfall amounts are considerably more constant than the monthly ones $(\mathrm{cv}=15 \%)$. According to the Walter's diagram [35], the temperature curve is below the rainfall level, so it is considered that, on average, each month there is still an excess of rainwater after evaporation.

The biomass was harvested manually and harvests were carried out in three harvest season (HS): autumn (25 November 2016; HS-1), winter (31 January 2017; HS-2) and spring (15 March 2017; HS-3). Biomass sampling was carried out on six different places within field trials. From each place, biomass was sampled on a surface $5 \mathrm{~m}$ long and $1 \mathrm{~m}$ wide. Biomass was cut to a height of $5 \mathrm{~cm}$ above the soil.

\subsection{Methods}

Valorization of fuel properties was conducted in the Laboratory for Biomass and Energy Efficiency in Agriculture, at the Department of Agricultural Technology, Storage and Transport (University of Zagreb Faculty of Agriculture). 
Sample preparation consisted of grinding in a laboratory grinder (IKA Analysentechnik GmbH, Staufen, Germany). After grinding, the samples were homogenized with a mortar and pestle. Each homogenized sample was analyzed in three replicates for each sample.

For proximate analysis, the samples were characterized according to standard methods: moisture content [36] in a laboratory oven (INKO ST-40, INKOLAB d.o.o., Zagreb, Croatia). Ash content [37], fixed carbon (by difference) and volatile matter [38] were determined by use of a muffle furnace (Nabertherm Controller B170, Nabertherm GmbH, Lilienthal, Germany).

Heating value, lower heating value was obtained by calculation, after the higher heating value had been determined by the EN 14918:2010 method [39] in an adiabatic calorimeter (IKA, Staufen im Breisgau, Germany).

Ultimate analysis, total carbon $(\mathrm{C})$, hydrogen $(\mathrm{H})$, nitrogen $(\mathrm{N})$ and sulfur $(\mathrm{S})$ were determined by dry combustion in a Vario Macro CHNS analyzer (Elementar Analysensysteme GmbH, Langenselbold, Germany), according to reported protocols $[40,41]$. The oxygen $(\mathrm{O})$ was calculated by difference.

Cell wall composition, determination of cellulose, hemicellulose and lignin content was conducted by the modified standard method ISO 5351-1:2002 [42].

For macro- and micro-elements, the quantity of macro-elements (sodium $-\mathrm{Na}$; magnesium $-\mathrm{Mg}$; potassium-K; calcium-Ca) and micro-elements (iron-Fe; zinc- $\mathrm{Zn}$; chromium-Cr; nickel-Ni) in the samples was determined by HRN EN ISO 16967:2015 methods [43] in an AAnalyst 400atomic absorption spectrometer (Perkin Elmer, Waltham, MA, USA), with the samples previously prepared in a microwave oven [44].

Statistical analysis was conducted according to the GLM procedure in the SAS system package version 8.00 [45].

\section{Results and Discussion}

\subsection{Proximate Analysis and Lower Heating Value}

Proximate analysis is one of the most important characterization methods during biomass thermal conversion. It consists of determining moisture, ash, volatile matter and fixed carbon contents of raw biofuels [46], while the lower heating value represents one of the basic parameters for evaluation of biomass as solid fuel. Table 2 presents the abovementioned parameters of the Sida hermaphrodita biomass in the three harvest seasons.

Table 2. Proximate analysis and lower heating value of the investigated Sida hermaphrodita biomass.

\begin{tabular}{cccccc}
\hline \multirow{2}{*}{ Harvest Season } & \multicolumn{5}{c}{ Parameters } \\
\cline { 2 - 6 } & Moisture (\%) & Ash (\%, db) & Fixed Carbon (\%, db) & Volatile Matter (\%, db) & $\begin{array}{c}\text { Lower Heating } \\
\text { Value (MJ/kg, db) }\end{array}$ \\
\hline HS-1 & $45.21 \mathrm{a} \pm 0.19$ & $9.27 \mathrm{a} \pm 0.42$ & $3.54 \mathrm{c} \pm 0.42$ & $84.19 \mathrm{~b} \pm 0.42$ & $17.69 \mathrm{ba} \pm 0.14$ \\
\hline HS-2 & $24.87 \mathrm{~b} \pm 0.08$ & $2.85 \mathrm{~b} \pm 0.71$ & $5.08 \mathrm{~b} \pm 0.06$ & $88.87 \mathrm{a} \pm 0.07$ & $18.31 \mathrm{a} \pm 0.09$ \\
\hline HS-3 & $18.64 \mathrm{c} \pm 0.17$ & $1.94 \mathrm{c} \pm 0.31$ & $6.21 \mathrm{a} \pm 0.98$ & $87.29 \mathrm{a} \pm 0.98$ & $17.56 \mathrm{~b} \pm 0.18$ \\
\hline & $\mathrm{db}=$ dry basis; different letters within columns indicate significant differences at the 5\% level.
\end{tabular}

Moisture content is the key factor that determines the net energy content of biomass material and how it influences the calorific value, combustion efficiency and combustion temperature $[47,48]$. Expectedly, by delaying the harvest from autumn to spring, there was a statistically significant reduction of moisture in the harvested biomass, which directly influenced the quality of the raw material for the direct combustion process. The moisture content in biomass of energy crops, including Sida hermaphrodita, primarily relates to agro-ecological conditions of the location where the crop is cultivated. The moisture content determined in the third harvest season enables safe storage of the harvested biomass without previously using energy inputs for drying the material, which is not the case with the moisture contents found in the first and the second harvest seasons. Stolarski et al. [49] 
determined that moisture loss was from $42.76 \%$ (November) to $17.99 \%$ (April), while Jablanowski et al. [50] found the moisture content of $12 \%$ in the harvest which was carried out in January.

Non-combustible content in biomass is referred to as ash [48] and it is an undesirable ingredient because of its catalytic influence on thermal decomposition [51]. The statistical analysis makes it possible to observe that, by delaying the harvest, the ash content was significantly reduced. Stolarski et al. [49] also determined the reduction of ash content from $3.09 \%$ to $2.36 \%$ by delaying the harvest from November to April. Furthermore, the average ash content in biomass of Sida hermaphrodita was determined by Šiaudinis et al. [52] at 6.07\% (pellet) in September/October harvest, by Jablanowski et al. [50] at $2.84 \%$ in January harvest. Not specifying the time of harvest, different authors [53-55] quote average ash contents of 2.9 to $5.2 \% ; 2.63 \% ; 3.75 \%$, respectively. Comparing our own data with the literature, it can be observed that the analysis of the biomass harvested in the autumn season showed a higher ash content. The quoted ash values from the later harvest seasons as well as the determined average value $(4.68 \%)$ are in line with the literature data. Of all proximate analyses shown in Table 1 only the ash content is valorized in the CEN/TS 14961:2005 specification for solid biofuels [33], and for Miscanthus the typical value is $4 \%$, which is markedly higher than the value found in the second and the third harvesting season.

Fixed carbon represents the quantity of carbon trapped in biomass by the photosynthetic process: a higher content of fixed carbon represents a higher biomass quality because of its increased heating value $[47,56]$. As for the two previous parameters, the fixed carbon content was statistically significantly impacted by harvest time and the delayed harvesting also resulted in enhanced quality of biomass in terms of combustion properties. The average fixed carbon content in Sida hermaphrodita biomass was $4.94 \%$, which is significantly below $17.14 \%$, the value which Howaniec and Smolinski reported without specifying the harvest season [54].

Another important consideration in the proximate analysis, when it comes to energetic value, are volatile components that are released by heating organic substances at high temperatures [57].

Unlike all other proximate analyses, harvest delay only slightly lowered the quality of biomass due to an increased volatile matters content. Statistical analysis determined significant difference between the first and the other two harvest seasons.

Howaniec and Smolinski [54] determined a volatile matters content of $71.47 \%$, while Stolarski et al. [58] determined $78.49 \%$ in a spring (March) biomass harvest. Comparing these values with the average volatile matters found in this investigation $(86.78 \%)$, it can be observed that there is a larger variation in this parameter. As for comparison with the literature data, investigations about influence of the harvest time on fixed carbon and volatile matters in Sida hermaphrodita have not been found in the available literature.

The quality of any biomass or fuel can be observed through the amount of heat (energy) generated from a fuel unit mass [8]. The calorific value can be expressed as higher heating value (HHV) and lower heating value (LHV). The latent heat contained in the water vapor cannot always be used effectively and, therefore, LHV is the appropriate value to present energy available for subsequent use [56]. Delaying the harvest time statistically influenced the LHV in the investigated biomass. However, a linear increase in LHV in line with decreasing moisture content in the harvested biomass was not observed, and the highest determined value was analyzed in the second harvest season (January). Similar tendency in calorific value was found by Stolarski et al. [49] in the HHV analysis of Sida hermaphrodita biomass (September 18.71 MJ/kg; January 18.80 MJ/kg; March 18.72 MJ/kg). Also, authors $[50,52,58]$ were looking into LHV in the investigated crop in relation to harvest seasons and found values of $16.92 \mathrm{MJ} / \mathrm{kg}$ (March), $17.82 \mathrm{MJ} / \mathrm{kg}$ (September/October) and 16.79 MJ/kg (January), successively. The average value of the determined LHV of $17.85 \mathrm{MJ} / \mathrm{kg}$ indicates that Sida hermaphrodita is a valuable energy raw material for the direct combustion process. In comparison to a typical LHV value for Miscanthus in CEN/TS 14961:2005 specification [33] (18.4 MJ/kg), it can be observed that they were somewhat lower in the investigated biomass. 


\subsection{Ultimate Analysis}

For understanding of the feedstock suitability for energy production it is important to determine the ultimate analysis as the basic composition of a feedstock [59]. It is determined through the weight percentages of chemical elements (carbon, hydrogen, nitrogen, oxygen and sulfur) in the biomass [60]. Table 3 presents the mentioned parameters of Sida hermaphrodita biomass in relation to the three harvest seasons.

Table 3. Ultimate analysis of the investigated Sida hermaphrodita biomass.

\begin{tabular}{|c|c|c|c|c|c|}
\hline \multirow{2}{*}{ Harvest Season } & \multicolumn{5}{|c|}{ Parameters } \\
\hline & $C(\%, d b)$ & $N(\%, d b)$ & $\mathrm{O}(\%, \mathrm{db})$ & $S(\%, d b)$ & $\mathrm{H}(\%, \mathrm{db})$ \\
\hline HS-1 & $46.79 \mathrm{~b} \pm 0.09$ & $1.82 \mathrm{a} \pm 0.10$ & $45.06 \mathrm{~b} \pm 0.04$ & $0.26 \mathrm{a} \pm 0.02$ & $6.07 \mathrm{a} \pm 0.06$ \\
\hline HS-2 & $32.22 c \pm 0.24$ & $0.22 \mathrm{c} \pm 0.01$ & $63.14 \mathrm{a} \pm 0.12$ & $0.19 \mathrm{~b} \pm 0.01$ & $4.24 b \pm 0.04$ \\
\hline HS-3 & $50.08 \mathrm{a} \pm 0.08$ & $0.65 b \pm 0.05$ & $42.95 c \pm 0.05$ & $0.23 \mathrm{ba} \pm 0.03$ & $6.10 \mathrm{a} \pm 0.09$ \\
\hline
\end{tabular}

Carbon, nitrogen, hydrogen and oxygen are the main components of solid fuels. During the combustion process carbon and oxygen react in an exothermic reaction by generating $\mathrm{CO}_{2}$ and $\mathrm{H}_{2} \mathrm{O}$. Thus, as internal $\mathrm{O}$ is a part of the comburent fraction, only $\mathrm{C}$ contributes positively to the HHV of a fuel [10]. Nussbaumer [61] emphasizes NOx emissions as one of the main environmental impacts of solid biomass combustion process. NOx can be formed via three different reaction mechanisms: thermal-NOx (from high temperature oxidation and atmospheric $\mathrm{N}_{2}$ ), prompt-NOx (from the reaction of fuel-derived radicals and atmospheric $\mathrm{N}_{2}$ ) and fuel-NOx (from the oxidation of nitrogen chemically bound in the fuel) [62]. Regarding the fact that higher amounts of nitrogen affect the NOx emissions during combustion, nitrogen is considered to be an undesirable biomass component. Obernberger et al. [63] stated that agricultural biomass with respect to forests contains a higher concentration of nitrogen, leading to higher NOx emissions. However, they also cite the possibility of reducing NOx emissions by introducing so-called primary [64] and secondary measures [65], which ultimately can result in emission reductions of up to $95 \%$. Sulphur oxides $\left(\mathrm{SO}_{\mathrm{x}}\right)$ are formed during combustion and contribute significantly to particulate matter (PM) pollution and acid rain [48]. Furthermore, higher hydrogen content determines and leads to a higher value of LHV $[11,66]$.

By use of statistical analysis it could be determined that all investigated elements showed significance in relation to the time of biomass harvesting. The analysis of biomass harvested in autumn showed a lower quality of biomass for the combustion process compared to the biomass harvested in the following spring.

Relative to the different harvest seasons, Stolarski et al. [49] determined the contents of carbon, hydrogen and sulfur in the investigated biomass at $46.08 \%, 5.46 \%, 0.038 \%$ (November); $47.71 \%, 5.71 \%$, $0.034 \%$ (January) and $48.89 \%, 5.80 \%, 0.023 \%$ (March), successively. As in this investigation, it is possible to observe positive changes in the biomass composition in terms of the above parameters and the harvest season. The average contents of carbon (42.56\%), hydrogen $(6.06 \%)$ and sulfur $(0.13 \%)$ in the biomass of Sida hermaphrodita were also determined by Kron et al. [67] who analyzed the biomass harvested in the summer months (July/August/September). Šiaudinis et al. [52] found in the Sida hermaphrodita biomass harvested in September/October a carbon content of $45.46 \%$, hydrogen content of $5.61 \%$ and sulfur content of $0.17 \%$, while Stolarski et al. [58] analyzed the same elements in the biomass harvested in March and found these contents to be $48.44 \%, 5.38 \%$ and $0.033 \%$, respectively. Comparing these values with the average ones in this work (carbon $43.03 \%$, hydrogen $5.47 \%$, sulfur $0.22 \%$ ), there is compatibility in all investigated elements, except in case of sulfur content which is markedly lower in the literature [49,58]. In the same season Stolarski et al. [58] found a nitrogen content of $0.35 \%$, while Šiaudinis et al. [52] analyzed this element at $0.75 \%$, and oxygen at $41.94 \%$. Kron et al. [67] analyzed the average contents of nitrogen and oxygen in the investigated material to be $1.25 \%$ and $49.86 \%$, respectively. Comparing the data from this investigation with the 
literature, it can be observed that the average nitrogen content determined in this investigation $(0.71 \%)$ is in line with the literature values of the analyzed biomass during dormancy. However, relative to the values obtained by Kron et al. [67], who analyzed the Sida hermaphrodita biomass that was harvested in the summer months, the nitrogen content was found to be lower. The determined average oxygen content $(50.38 \%)$ in this investigation is in line with the literature data with variations that were within expectations. Relative to typical values stated in the CEN/TS 14961:2005 specification [33] for C $(49 \%), \mathrm{H}(6.4 \%), \mathrm{N}(0.7 \%), \mathrm{O}(44 \%)$ and $\mathrm{S}(0.2 \%)$, it is possible to observe that the above values are in accordance with the values found in the third harvest season. Parallel to the values determined in the first and the second harvest season certain variation can be observed.

\subsection{Cell Wall Composition}

Lignocellulose is made up of three components: lignin, cellulose, and hemicellulose, whose content significantly varies depending on type of the biomass [68]. Lignin constitutes the key component of the cell wall, and biomass with higher lignin content is more suitable for electricity/heat energy production by direct combustion $[51,56,69]$. A high lignin content in the biomass results in a higher HHV. Cellulose and hemicellulose are higher in oxygen in relation to lignin, so cellulose has lower heating value than lignin [70]. Table 4 shows the values in the cell wall composition of the biomass of Sida hermaphrodita in relation to the three investigated harvest seasons.

Table 4. Cell wall composition of Sida hermaphrodita biomass.

\begin{tabular}{cccc}
\hline \multirow{2}{*}{ Harvest Season } & \multicolumn{4}{c}{ Parameters } \\
\cline { 2 - 4 } & Cellulose $\mathbf{( \% ,}, \mathbf{d b})$ & Hemicellulose $\mathbf{( \% ,} \mathbf{d b})$ & Lignin $\mathbf{( \% ,} \mathbf{d b})$ \\
\hline HS-1 & $39.03 \mathrm{~b} \pm 1.06$ & $30.08 \mathrm{a} \pm 2.08$ & $19.88 \mathrm{~b} \pm 1.10$ \\
\hline $\mathrm{HS}-2$ & $43.89 \mathrm{a} \pm 1.15$ & $30.10 \mathrm{a} \pm 1.09$ & $23.68 \mathrm{a} \pm 1.06$ \\
\hline HS-3 & $45.04 \mathrm{a} \pm 1.03$ & $27.33 \mathrm{a} \pm 1.12$ & $25.45 \mathrm{a} \pm 1.10$ \\
\hline $\mathrm{db}=$ dry basis; different letters within a column indicate significant differences at the $5 \%$ level.
\end{tabular}

The statistical analysis demonstrated that delaying the harvest from autumn to spring enabled the increase in the cellulose and lignin contents, while the hemicellulose content only slightly varied. Jablanoeski et al. [50] state that the increased lignin and cellulose contents is associated with increasing dry matter content, which is the case in this investigation as well. Wright et al. [71] quote the cell wall composition of the selected energy crops (switchgrass, Miscanthus, Arundo), and the average expected values are: $31-51 \%$ cellulose, $24-50 \%$ hemicellulose and $17-26 \%$ lignin. As for the observed crop, Wróblewska et al. [72] determined the contents of cellulose (41.02\%) and lignin (20.52\%). With regard to the average values found in this investigation (cellulose $42.65 \%$, hemicellulose $29.17 \%$, lignin $23.00 \%$ ) it can be observed that all parameters are in accordance with the literature data. CEN/TS 14961:2005 specification [33] does not evaluate the cell wall composition.

\subsection{Macro and Micro Element}

Elemental composition has a significant effect on biomass quality and combustion process parameters [73] and may cause serious problems in the furnaces, including occurrence of ash slagging, corrosion and dirt [74]. The extent of these problems is closely related to the chemical composition of the used biomass [75]. The proportions of individual elements should be studied individually, but also in their mutual relation. For example, due to a significant impact on the occurrence of ash slagging, the ratio between $\mathrm{K}, \mathrm{Ca}$ and $\mathrm{Si}$ should be taken into account in the biomass quality assessment. Reumerman and Van den Berg [75] have found that biomass with high $\mathrm{Si} / \mathrm{K}$ and $\mathrm{Ca} / \mathrm{K}$ ratio contributes to lower slag occurrence. $\mathrm{K}$ and $\mathrm{Na}$, in combination with $\mathrm{Cl}$ and $\mathrm{S}$, are involved in corrosion. These elements are partially vaporized during combustion, forming alkali chlorides condensing on the surface of the heat exchanger and reacting with flue gas, forming sulfates and releasing $\mathrm{Cl}[76,77]$. 
$\mathrm{Ca}$ and $\mathrm{Mg}$ usually increase the ash melting point, while $\mathrm{K}$ decreases it [78,79]. Therefore, the fuel is better if it is present a lower proportion of $\mathrm{K}$ and $\mathrm{Na}[76,80]$. Furthermore, during combustion, volatile elements such as $\mathrm{Cl}$ may form submicron particles condensing as salts which, with the presence of high temperatures, can cause K and Si to form sticky deposits in the combustion chamber [81,82]. Together with $\mathrm{Cl}$ and $\mathrm{S}, \mathrm{K}$ and $\mathrm{Na}$ play a major role in corrosion mechanisms. Moreover, low melting mixtures of alkali and heavy metal chlorides can also cause corrosion by sulfating reactions [63]. In the case of a high melting point, the presence of $\mathrm{K}$ or $\mathrm{Ca}, \mathrm{Si}$ is readily reacted by forming alkaline silicates having significantly lower melting points. P may also increase the potential deposition of slags [82]. Alkaline elements such as $\mathrm{Na}, \mathrm{Mg}$ or salts (e.g., chloride, sulfide) easily form a mixture of two or more solid phases which thereby lower the melting point [83]. Si in the combination with $\mathrm{Na}$ and $\mathrm{K}$ can lead to the formation of silicates in the fly ash particles [77]. These processes promote ash melting on the combustion grid and the appearance of slag [80]. This fact must be considered when selecting the appropriate combustion and temperature control technology [79].

Table 5 shows the investigated macro and micro elements in biomass of Sida hermaphrodita in relation to the three harvest seasons, as well as typical values of Miscanthus biomass stated in the technical specification CEN/TS 14961:2005 [33].

Table 5. Macro and micro elements of the investigated Sida hermaphrodita biomass and typical values for Miscanthus biomass [33].

\begin{tabular}{ccccc}
\hline \multirow{2}{*}{ Parameters } & \multicolumn{3}{c}{ Harvest Season } & \multirow{2}{*}{ CEN/TS 14961:2005 } \\
\cline { 2 - 4 } & \multicolumn{5}{c}{ HS-1 } & HS-3 & \\
\hline \multicolumn{5}{c}{ Macroelements $(\mathrm{mg} / \mathrm{kg}, \mathrm{db})$} \\
$\mathrm{Na}$ & $29.76 \mathrm{a} \pm 0.60$ & $27.29 \mathrm{a} \pm 3.40$ & $20.73 \mathrm{~b} \pm 0.60$ & $200-500$ \\
$\mathrm{Kg}$ & $501.7 \mathrm{a} \pm 0.72$ & $499.7 \mathrm{a} \pm 1.61$ & $500.1 \mathrm{a} \pm 2.40$ & $300-900$ \\
$\mathrm{Ca}$ & $12,360 \mathrm{a} \pm 61.29$ & $794.6 \mathrm{c} \pm 23.53$ & $11,340 \mathrm{~b} \pm 30.71$ & $1000-11,000$ \\
& $7259 \mathrm{a} \pm 348.73$ & $7583 \mathrm{a} \pm 204.59$ & $7569 \mathrm{a} \pm 159.81$ & $900-3000$ \\
\hline $\mathrm{Fe}$ & $48.87 \mathrm{c} \pm 1.03$ & $60.73 \mathrm{~b} \pm 0.78$ & $75.39 \mathrm{a} \pm 0.51$ & $40-400$ \\
$\mathrm{Zn}$ & $13.58 \mathrm{a} \pm 2.28$ & $8.92 \mathrm{~b} \pm 0.64$ & $10.27 \mathrm{~b} \pm 1.07$ & $10-20$ \\
$\mathrm{Cr}$ & $5.26 \mathrm{a} \pm 1.74$ & $5.40 \mathrm{a} \pm 1.88$ & $4.73 \mathrm{a} \pm 3.12$ & $0.4-6.0$ \\
$\mathrm{Ni}$ & $5.71 \mathrm{a} \pm 1.64$ & $5.43 \mathrm{a} \pm 3.49$ & $6.72 \mathrm{a} \pm 1.47$ & $0.5-5.0$ \\
\hline
\end{tabular}

$\mathrm{db}=$ dry basis; different letters within a column indicate significant differences at the $5 \%$ level.

Delaying the harvest from autumn to spring resulted in statistically significant changes of the biomass composition in the magnesium, potassium, iron and zinc contents.

Compared to the different fertilization treatments during cultivation of Sida hermaphrodita culture Borkowska and Lipiński [84] investigated the values of the selected elements in the cultivated biomass. Comparing their results K 3870 (mg/kg, db), Mg 560 (mg/kg, db), Ca 7290 (mg/kg, db) and Na 90 $(\mathrm{mg} / \mathrm{kg}, \mathrm{db})$, with results analyzed in this paper, there is a slight decrease in the $\mathrm{Mg}$ and Ca content, and a more significant one for $\mathrm{K}$ and $\mathrm{Na}$ content. The same elements were also investigated by Monti et al., [85] and in the stems of six different energy cultures they found average values for K $6774(\mathrm{mg} / \mathrm{kg})$, $\operatorname{Mg} 1260(\mathrm{mg} / \mathrm{kg})$, Ca $3325(\mathrm{mg} / \mathrm{kg})$, and Na $2174(\mathrm{mg} / \mathrm{kg})$. According to the above it can be said that the content of certain macro- and micro-elements depends on a variety of agro-ecological factors such as climatic conditions of cultivation location, soil type, cultivated culture, agro-techniques and harvesting time. Regarding the CEN/TS 14961:2005 specification [33], it can be observed that the analyzed values of magnesium, potassium, iron, zinc and chrome are in accordance with or only vary slightly from the typical values, while larger divergences are noted in sodium and calcium. Given the content of macro- and micro-elements in the biomass in influenced by several agro-ecological factors and planting locations, a certain divergence of the analyzed values from the CEN/TS 14961:2005 specification [33] was to be expected. 


\section{Conclusions}

Different harvest seasons have an influence on the fuel properties of Sida hermaphrodita biomass. Delaying harvest from autumn toward spring resulted in significant variations in the biomass composition in all investigated parameters except for magnesium, calcium, chrome and nickel. The delayed harvest had a positive influence on the quality of the investigated biomass, primarily due to lowering the moisture, ash, nitrogen, sulfur, and carbon contents, but also lead to increasing levels of fixed carbon and lignin. All investigated combustion parameters are in line with typical values in CEN/TS 14961:2005 for solid fuel or show variations within the expected range. The determined values of potassium, and sulfur as well, can be one of the aggravating factors during the use of biomass in the combustion process. The conducted investigations indicate that biomass of the crops Sida hermaphrodita is potentially a good quality raw material for the direct combustion process. In the case of poor quality furnaces and improper technical handling of biomass, slag and corrosion are possible, which is not characteristic of Sida hermaphrodita only but also of other agricultural biomass. Croatia has no experience in cultivation and energy utilization of Sida hermaphrodita, and the results of the investigation have contributed to the adoption of the Law on Short Rotation Crops. Given the fact that Croatia has significant tracts of abandoned agricultural land, the introduction of such cultures would have an impact on their revitalization without affecting the current production of food and feed. It must be emphasized that the eastern part of Europe does not have a biomass stock market, and the introducing of production of crops for green energy would encourage the establishment of such a market.

Author Contributions: Conceptualization and writing—original draft preparation, N.B.; writing-review and editing and supervision, T.K.; methodology, formal analysis and investigation, A.M., J.L. and M.G.

Funding: This research was funded by the Ministry of Agriculture as part of the VIP project "The potential of energy crops Sida hermaphrodita on organic farm".

Conflicts of Interest: The authors declare no conflict of interest.

\section{References}

1. EC. Communication (2014) 0015 from the Commission to the European Parliament, The Council, The European Economic and Social Committee and The Committee of The Regions. A Policy Framework for Climate and Energy in the Period from 2020 to 2030, COM/2014/015 Final. Available online: https: / / www.eea.europa.eu/policy-documents/com-2014-15-final (accessed on 22 November 2018).

2. Paris Agreement, FCCC/CP/2015/L.9/Rev.1. Available online: https://unfccc.int/resource/docs/2015/ cop21/eng/109r01.pdf (accessed on 3 December 2018).

3. EC. Report from the Commission on Indirect Land-Use Change Related to Biofuels and Bioliquids; European Commission: Brussels, Belgium, 2010.

4. COM (2016) 767 Final/2 Proposal for a Directive of the European Parliament and of the Council on the Promotion of the Use of Energy from Renewable Sources (Recast); European Commission: Brussels, Belgium, 2017.

5. Zhou, A.; Thomson, E. The development of biofuels in Asia. Appl. Energy 2009, 86, 11-20. [CrossRef]

6. Tanger, P.; Field, J.L.; Jahn, C.E.; DeFoort, M.W.; Leach, J.E. Biomass for thermochemical conversion: Targets and challenges. Front. Plant. Sci. 2013, 4, 218. [CrossRef] [PubMed]

7. Mladenović, M.; Paprika, M.; Marinković, A. Denitrification techniques for biomass combustion. Renew. Sustain. Energy Rev. 2017, 82, 3350-3364. [CrossRef]

8. Kumar, R.; Pandey, K.K.; Chandrashekar, N.; Mohan, S. Effect of tree-age on calorific value and other fuel properties of Eucalyptus hybrid. J. For. Res. 2010, 21, 514-516. [CrossRef]

9. Castaño-Díaz, M.; Álvarez-Álvarez, P.; Tobin, B.; Nieuwenhuis, M.; Afif-Khouri, E.; Cámara-Obregón, A. Evaluation of the use of low-density LiDAR data to estimate structural attributes and biomass yield in a short-rotation willow coppice: An example in a field trial. Ann. For. Sci. 2017, 74, 16. [CrossRef]

10. Álvarez-Álvarez, P.; Pizarro, C.; Barrio-Anta, M.; Cámara-Obregón, A.; Bueno, J.L.M.; Álvarez, A.; Gutiérrez, I.; Burslem, D.F. Evaluation of Tree Species for Biomass Energy Production in Northwest Spain. Forests 2018, 9, 160. [CrossRef] 
11. Prochnow, A.; Heiermann, M.; Plöchl, M.; Amon, T.; Hobbs, P.J. Bioenergy from permanent grassland-A review: 2. Combustion. Bioresour. Technol. 2009, 100, 4945. [CrossRef]

12. Barglowicz, J. Content of chosen macroelements in biomass of Virginia mallow (Sida hermaphrodita Rusby). J. Cent. Eur. Agric. 2014, 15. [CrossRef]

13. Demirbas, A. Higher heating values of lignin types from wood and non-wood lignocellulosic biomasses. Energy Sources Part A 2017, 39, 592-598. [CrossRef]

14. Robson, P.; Mos, M.; Clifton-Brown, J.; Donnison, I. Phenotypic Variation in Senescence in Miscanthus: Towards Optimising Biomass Quality and Quantity. Bioenergy Res. 2012, 5, 95-105. [CrossRef]

15. Borkowska, H.; Molas, R. Two extremely different crops, Salix and Sida, as sources of renewable bioenergy. Biomass Bioenergy 2012, 36, 234-240. [CrossRef]

16. Mehmood, M.A.; Ibrahim, M.; Rashid, U.; Nawaz, M.; Ali, S.; Hussain, A.; Gull, M. Biomass production for bioenergy using marginal lands. Sustain. Prod. Consum. 2017, 9, 3-21. [CrossRef]

17. Mantineo, M.; D’Agosta, G.M.; Copani, V.; Patane, C.; Cosentino, S.L. Biomass yield and energy balance of three perennial crops for energy use in the semi-arid Mediterranean environment. Field Crops Res. 2009, 114, 204-213. [CrossRef]

18. Borkowska, H. Yields of Virginia fanpetals and willow on good wheat soil complex. Fragm. Agron. 2007, 2, 7-41.

19. Borkowska, H.; Wardzinska, K. Some effects of Sida hermaphrodita R. cultivation on sewage sludge. Pol. J. Environ. Stud. 2003, 10, 119-122.

20. Tworkowski, J.; Szczukowski, S.; Stolarski, M.J.; Kwiatkowski, J.; Graban, Ł. Productivity and properties of Virginia fanpetals biomass as fuel depending on the propagule and plant density. Fragm. Agron. 2014, 3, 115-125.

21. Borkowska, H.; Styk, B. Virginia Fanpetals (Sida hermaphrodita L. Rusby): Cultivation and Utilization Monograph; University of Life Sciences: Lublin, Poland, 2006; p. 69.

22. Kiesel, A.; Nunn, C.; Iqbal, Y.; Van der Weijde, T.; Wagner, M.; Özgüven, M.; Tarakanov, I.; Kalinina, O.; Trindade, L.M.; Clifton-Brown, J.; et al. Site-Specific Management of Miscanthus Genotypes for Combustion and Anaerobic Digestion: A Comparison of Energy Yields. Front. Plant. Sci. 2017, 8, 347. [CrossRef] [PubMed]

23. Iqbal, Y.; Kiesel, A.; Wagner, M.; Nunn, C.; Kalinina, O.; Hastings, A.F.S.J.; Clifton-Brown, J.C.; Lewandowski, I. Harvest Time Optimization for Combustion Quality of Different Miscanthus Genotypes across Europe. Front. Plant. Sci. 2017, 8, 727. [CrossRef]

24. Zub, H.W.; Arnoult, S.; Brancourt-Hulmel, M. Key traits for biomass production identified in different Miscanthus species at two harvest dates. Biomass Bioenergy 2011, 35, 637-651. [CrossRef]

25. Larsen, S.U.; Jørgensen, U.; Kjeldsen, J.B.; Lærke, P.E. Long-term Miscanthus Yields Influenced by Location, Genotype, Row Distance, Fertilization and Harvest Season. BioEnergy Res. 2014, 7, 620-635. [CrossRef]

26. Adler, P.R.; Sanderson, M.A.; Boateng, A.A.; Weimer, P.J.; Jung, H.J.G. Biomass Yield and Biofuel Quality of Switchgrass Harvested in Fall or Spring. Agron. J. 2006, 98, 1518-1525. [CrossRef]

27. Nazli, R.I.; Tansi, V.; Öztürk, H.H.; Kusvuran, A. Miscanthus, switchgrass, giant reed, and bulbous canary grass as potential bioenergy crops in a semi-arid Mediterranean environment. Ind. Crops Prod. 2018, 125, 9-23. [CrossRef]

28. Bilandzija, N.; Jurisic, V.; Voca, N.; Leto, J.; Matin, A.; Sito, S.; Kricka, T. Combustion properties of Miscanthus $\times$ giganteus biomass-Optimization of harvest time. J. Energy Inst. 2017, 90, 528-533. [CrossRef]

29. Baxter, X.C.; Darvell, L.I.; Jones, J.M.; Barraclough, T.; Yates, N.E.; Shield, I. Study of Miscanthus $\times$ giganteus ash composition-Variation with agronomy and assessment method. Fuel 2012, 95, 50-62. [CrossRef]

30. Kiesel, A.; Lewandowski, I. Miscanthus as biogas substrate. In Proceedings of the Conference Paper on the 23rd European Biomass Conference and Exhibition, Viena, Austria, 1-4 June 2014. [CrossRef]

31. Van Dyken, S.; Bakken, B.H.; Skjelbred, H.I. Linear mixed-integer models for biomass supply chains with transport, storage and processing. Energy 2010, 35, 1338-1350. [CrossRef]

32. Sowlati, T. Modeling of Forest and Wood Residues Supply Chains for Bioenergy and Biofuel Production. In Biomass Supply Chains Bioenergy Biorefining; Holm-Nielsen, J.B., Ehimen, E.A., Eds.; Elsevier: Amsterdam, The Netherland, 2016; pp. 167-190, ISBN 978-1-78242-366-9.

33. European Committee for Standardization. Solid Biofuels-Fuel Specifications and Classes; CEN: Brussels, Belgium, 2005. 
34. Zaninović, K.; Gajić-Čapka, M.; Perčec Tadić, M.; Vučetić, M.; Milković, J.; Bajić, A.; Cindrić, K.; Cvitan, L.; Katušin, Z.; Kaučić, D.; et al. Climate Atlas of Croatia 1961-1990, 1971-2000; Croatian Meteorological and Hydrological Service: Zagreb, Croatia, 2008; ISBN 978-953-7526-01-6.

35. Penzar, I.; Penzar, B. Agrometeorology Školska Knjiga; Croatian Meteorological and Hydrological Service: Zagreb, Croatia, 2000; ISBN 978-953-0-30678-3.

36. European Committee for Standardization. Solid Biofuels_Determination of Moisture Content, Oven Dry Method, Total Moisture, Simplified Method; CEN: Brussels, Belgium, 2009.

37. European Committee for Standardization. Solid Biofuels-Determination of Ash Content; CEN: Brussels, Belgium, 2009.

38. European Committee for Standardization. Solid Biofuels-Method for the Determination of the Content of Volatile Matter; CEN: Brussels, Belgium, 2009.

39. Croatian Committee for Standardization. Solid Biofuels_Determination of Calorific Value; HRN: Vukovara, Croatia, 2010.

40. Croatian Committee for Standardization. Solid Biofuels—Determination of Total Content of Carbon, Hydrogen and Nitrogen-Instrumental Methods; HRN: Vukovara, Croatia, 2011.

41. Croatian Committee for Standardization. Solid Biofuels-Determination of Total Content of Sulfur and Chlorine; HRN: Vukovara, Croatia, 2011.

42. International Organization for Standardization. Cellulose in Dilute Solutions_Determination of Limiting Viscosity Number; ISO: Geneva, Switzerland, 2002.

43. Croatian Standard Institute. Solid Biofuels—Determination of Major Elements—Al, Ca, Fe, Mg, P, K, Si, Na and Ti; HRN: Vukovara, Croatia, 2015.

44. Croatian Standard Institute. Solid Biofuels-Determination of Minor Elements; HRN: Vukovara, Croatia, 2015.

45. Software SAS 9.3: SAS; Institute Inc.: Cary, NC, USA, 2001.

46. García, R.; Pizarro, C.; Lavín, A.G.; Bueno, J.L. Biomass Proximate Analysis using Thermogravimetry. Bioresour. Technol. 2013, 139, 1-4. [CrossRef] [PubMed]

47. Obernberger, I.; Thek, G. Physical characterisation and chemical composition of densified biomass fuels with regard to their combustion. Biomass Bioenergy 2004, 27, 653-669. [CrossRef]

48. Parmar, K. Biomass-An Overview on Composition Characteristics and Properties. IRA-JAS 2017, 7, 42-51. [CrossRef]

49. Stolarski, M.J.; Krzyżaniak, M.; Śnieg, M.; Słomińska, E.; Piórkowski, M.; Filipkowski, R. Thermophysical and chemical properties of perennial energy crops depending on harvest period. Int. Agrophys. 2014, 28, 201-211. [CrossRef]

50. Jablonowski, N.D.; Kollmann, T.; Nabel, M.; Damm, T.; Klose, H.; Müller, M.; Bläsing, M.; Seebold, S.; Krafft, S.; Kuperjans, I.; et al. Valorization of Sida (Sida hermaphrodita) biomass for multiple energy purposes. GCB Bioenergy 2017, 9, 202-214. [CrossRef]

51. Hodgson, E.M.; Fahmi, R.; Yates, N.; Barraclough, T.; Shield, I.; Allison, G.; Bridgwater, A.V.; Donnison, I.S. Miscanthus as a feedstock for fast-pyrolysis: Does agronomic treatment affect quality? Bioresour. Technol. 2010, 101, 6185-6191. [CrossRef]

52. Šiaudinis, G.; Jasinskas, A.; Šarauskis, E.; Steponavičius, D.; Karčauskienė, D.; Liaudanskienė, I. The assessment of Virginia mallow (Sida hermaphrodita Rusby) and cup plant (Silphium perfoliatum L.) productivity, physico-mechanical properties and energy expenses. Energy 2015, 93, 606-612. [CrossRef]

53. Kacprzak, M.; Ociepa, A.; Bien, J. The influence of soil fertilization on the amounts of ashes and contents of heavy metals in biomass ashes. Arch. Combust. 2010, 30, 125-131.

54. Howaniec, N.; Smoliński, A. Steam gasification of energy crops of high cultivation potential in Poland to hydrogen-rich gas. Int. J. Hydrogen Energy 2011, 36, 2038-2043. [CrossRef]

55. Slepetys, J.; Kadziuliene, Z.; Sarunaite, L.; Tilvikiene, V.; Kryzeviciene, A. Biomass Potential of Plants Grown for Bioenergy Production. International Scientific Conference Renewable Energy and Energy Efficiency. 2012, 66-72. Available online: http://llufb.llu.lv/conference/Renewable_energy_energy_efficiency/Latvia_Univ_ Agriculture_REEE_conference_2012-66-72.pdf (accessed on 4 December 2018).

56. McKendry, P. Energy production from biomass (part 1): Overview of biomass. Bioresour. Technol. 2002, 83, 37-46. [CrossRef]

57. García, R.; Pizaro, C.; Lavín, A.G.; Bueno, J.J. Characterization of Spanish biomass wastes for energy use. Bioresour. Technol. 2012, 103, 249-258. [CrossRef] [PubMed] 
58. Stolarski, M.J.; Szczukowski, S.; Tworkowski, J.; Krzyżaniak, M.; Gulczyński, P.; Mleczek, M. Comparison of quality and production cost of briquettes made from agricultural and forest origin biomass. Renew. Energy 2013, 57, 20-26. [CrossRef]

59. Sulaiman, S.A.; Bamufleh, H.S.; Tamili, S.N.A.; Inayat, M.; Naz, M.Y. Characterization of date palm fronds as a fuel for energy production. Bull. Chem. Soc. Ethiop. 2016, 30, 465-472. [CrossRef]

60. Yin, C.Y. Prediction of higher heating values of biomass from proximate and ultimate analyses. Fuel 2011, 90, 1128-1132. [CrossRef]

61. Nussbaumer, T. Combustion and co-combustion of biomass. In Proceedings of the 12th European Biomass Conference, Amsterdam, The Netherland, 17 June 2002; Volume I, pp. 31-37, ISBN 88-900442-5-X.

62. Williams, A.; Jones, J.M.; Ma, L.; Pourkashanian, M. Pollutants from the combustion of solid biomass fuels. Prog. Energy Combust. Sci. 2012, 38, 113-137. [CrossRef]

63. Obernberger, I.; Brunner, T.; Bärnthaler, G. Chemical properties of solid biofuels-Significance and impact. Biomass Bioenergy 2006, 30, 973-982. [CrossRef]

64. Keller, R. Primarmassnahmen zur NOx-Minderung bei der Holzverbrennung mit dem Schwerpunkt der Luftstufung; Laboratorium furEnergiesysteme, Ed.; ETH Zurich: Zurich, Switzerland, 1994.

65. Obernberger, I. Physical Characteristics and Chemical Composition of Solid Biomass Fuels; Eindhofen University of Technology, Department for Mechanical Engineering, Section Process Technology, Eds.; Eindhofen University: Eindhofen, The Netherlands, 2003.

66. Clarke, S.; Preto, F. Biomass Burn Characteristics; Ministry of Agriculture, Food and Rural Affairs: Guelph, ON, Canada, 2011; pp. 11-33.

67. Kron, I.; Porvaz, P.; Král'ová-Hricindová, A.; Tóth, Š.; Sarvaš, J.; Polák, M. Green harvests of three perennial energy crops and their chemical composition. IJAER 2017, 3, 2870-2883.

68. Jørgensen, H.; Bach, K.J.; Felby, C. Enzymatic conversion of lignocellulose into fermentable sugars: Challenges and opportunities. Biofuels Bioprod. Bioref. 2007, 1, 119-134. [CrossRef]

69. Predojević, Z. Postupci pripreme lignocelulozne sirovine za dobivanje bietanola. Hem. Ind. 2010, 64, $283-310$. [CrossRef]

70. Lewandowski, I.; Clifton-Brown, J.C.; Andersson, B.; Basch, G.; Christian, D.G.; Jorgensen, U.; Jones, M.B.; Riche, A.B.; Schwarz, K.U.; Tayebi, K.; et al. Enviroment and harvest time affect the combustion qualities of Miskantus genotypes. Agron. J. 2003, 95, 1274-1280. [CrossRef]

71. Wright, L.; Boundy, B.; Perlack, B.; Davis, S.; Saulsbury, B. Biomass Energy Data Book; US Department of Energy Publications: Washington, DC, USA, 2006; Volume 1.

72. Wróblewska, H.; Komorowicz, M.; Pawłowski, J.; Cichy, W. Chemical and energetical properties of selected lignocellulosic raw materials. Folia For. Pol. 2009, 40, 67-78.

73. Stolarski, M.J.; Niksa, D.; Krzyżaniak, M. Elemental composition of willow short rotation crops biomass depending on variety and harvest cycle. Biomass Bioenergy 2017, 105, 342-350. [CrossRef]

74. Cassida, K.A.; Muir, J.P.; Hussey, M.A.; Read, J.C.; Venuto, B.C.; Ocumpaugh, W.R. Biofuel component concentrations and yields of switchgrass in South central US environments. Crop. Sci. 2005, 45, 682-692. [CrossRef]

75. Reumerman, P.J.; Van den Berg, D. Reduction of Fouling, Slagging and Corrosion Characteristics of Miscanthus (the BIOMIS Project); European Commission: Brussels, Belgium, 2002.

76. Masia, A.A.T.; Buhre, B.J.P.; Gupta, R.P.; Wall, T.F. Characterising ash of biomass and waste. Fuel Process. Technol. 2007, 88, 1071-1081. [CrossRef]

77. Khan, A.A.; de Jong, W.; Jansens, P.J.; Spliethoff, H. Biomass combustion in fluidized bed boilers: Potential problems and remedies. Fuel Process. Technol. 2009, 90, 21-50. [CrossRef]

78. Obernberger, I. Nutzung Fester Biomasse in Verbrennungsanlagen unter Besonderer Berucksichtigung des Verhaltens Aschebildender Elemente. Schriftenreihe "Thermische Biomassenutzung"; Dbv-Verlag der Technischen Universitat Graz: Graz, Austria, 1997; ISBN 3-7041-0241-5.

79. Van Loo, S.; Koppejan, J. Handbook of Biomass Combustion and Co-Firing; IEA: Paris, France, 2002; ISBN 9036517737.

80. Van Loo, S.; Koppejan, J. The Handbook of Biomass Combustion and Co-Firing; Earthscan: London, UK, 2008; ISBN 9781844072491.

81. Bläsing, M.; Müller, M. Mass spectrometric investigations on the release of inorganic species during gasification and combustion of Rhenish lignite. Fuel 2010, 89, 2417-2424. [CrossRef] 
82. Bläsing, M.; Müller, M. Mass spectrometric investigations on the release of inorganic species during gasification and combustion of German hard coal. Combust. Flam 2010, 157, 1374-1381. [CrossRef]

83. Porbatzki, D.; Stemmler, M.; Müller, M. Release of inorganic trace elements during gasification of wood, straw, and miscanthus. Biomass Bioenergy 2011, 35, 79-86. [CrossRef]

84. Borkowska, H.; Lipiński, W. The content of selected elements in the biomass of several species of energy plants. Acta Agrophys. 2007, 10, 287-292.

85. Monti, A.; Di Virgiliob, N.; Venturia, G. Mineral composition and ash content of six major energy crops. Biomass Bioenergy 2008, 32, 216-223. [CrossRef] 